\title{
MENINGKATKAN MOTIVASI BERPRESTASI SISWA MELALUI LAYANAN BIMBINGAN KELOMPOK DENGAN MEDIA FILM
}

\author{
MUHAMMAD TAJUL ARIFIN
}

MTs Negeri 2 Pekalongan

Email : tajularifinbk@gmail.com

\begin{abstract}
ABSTRAK
Penelitian ini bertujuan untuk meningkatkan motivasi berprestasi melalui layanan bimbingan kelompok dengan media film. Metode penelitian eksperimen menggunakan desain one group pretest-post dengan melibatkan 10 siswa dari kelas VII dan VIII yang mempunyai motivasi berprestasi rendah sebagai anggota kelompok. Hasil penelitian ini adalah diperolehnya kondisi motivasi berprestasi siswa dan menunjukkan bahwa siswa yang memperoleh bantuan layanan bimbingan dengan media film mengalamai peningkatan motivasi berpretasinya dibandingkan sebelum mengikuti layanan bimbingan kelompok dengan media film.
\end{abstract}

Kata Kunci : Motivasi Berprestasi, Bimbingan Kelompok, Media Film

\section{ABSTRACT}

This study aims to improve achievement motivation through community service with filmm media. The research method used the design of one pretest-post group involving 10 students from class VII and VIII with low achievement motivation as group member. The result of this research is the achievement of student achievement motivation and show that the students who get the assistance of counseling service with the film media experience the improvement of the motivation of the perception than before following the group guidance service with the film media.

Keywords: achievemenet motivation, group guidance with movie.

\section{PENDAHULUAN}

Seseorang yang memiliki motivasi berprestasi tinggi cenderung untuk selalu berusaha mencapai apa yang diinginkan walaupun mengalami hambatan dan kesulitan dalam meraihnya. Hal ini seseuai dengan penelitian yang dilakukan oleh Sugiyanto (2009) yaitu ada menunjukkan bahwa semakin tinggi motivasi berprestasi maka prestasi akademik akan semakin tinggi pula. Demikian sebaliknya jika motivasi berprestasi rendah maka prestasi juga semakin rendah. Menurut Wastie, Lydia, \& Cicilia, (2015) Salah satu faktor yang mempengaruhi prestasi adalah motivasi. Dengan adanya motivasi, maka belajar lebih keras, ulet, tekun dan memiliki konsentrasi penuh dalam proses belajar. Motivasi yang paling penting dalam dunia pendidikan adalah motivasi berprestasi.

Menurut Taiyeb, Bahri \& Razak (2012) Motivasi berprestasi adalah keinginan yang mengarahkan seseorang untuk selalu meningkatkan prestasinya dengan bekerja keras dan bekerja untuk mencapai mutu kerja sebaik baiknya atau dapat juga dikatakan bahwa motivasi berprestasi sebagai suatu dorongan dalam diri seseorang untuk melakukan atau mengerjakan suatu kegiatan dengan sebaik baiknya agar mencapai prestasi yang baik. Selanjutnya motivasi berprestasi adalah daya penggerak dalam diri siswa untuk mencapai taraf prestasi setinggi mungkin sesuai dengan yang ditetapkan oleh siswa itu sendiri maka, siswa dituntut untuk bertanggung jawab mengenai taraf keberhasilan yang akan diperolehnya. Siswa yang memiliki motivasi berprestasi yang baik memiliki upaya untuk mencapai taraf keberhasilan yang tinggi dan senang dengan lingkungan yang kompetitif.

Menurut Toni, Lasmawan \& Arnyana (2013) bahwa Siswa yang mempunyai motivasi berprestasi tinggi cendrung ingin sukses dalam belajarnya. Keberhasilan seseorang dalam mencapai hasil yang terbaik dalam hidupnya pada dasarnya tidak terlepas dengan motivasi belajar, dan harapan suksesnya, serta menghindari kegagalan. Indikator motivasi berpestasi adalah tekun dalam menghadapi tugas, ulet dan tidak mudah putus asa, menerima pelajaran 
dengan baik untuk mencapai prestasi, senang belajar mandiri, senang, rajin dalam belajardan penuh semangat, berani mempertahankan pendapat bila benar; dan suka mengerjakan soal-soal latihan (Sardiman, $2002: 82-83$ ).

Menurut Purwanto (2014) secara keseluruhan, motivasi berprestasi siswa umumnya masih rendah. Sangat banyak dijumpai siswa yang ingin memperoleh nilai rapor bagus, lulus ujian dan masuk perguruan tinggi tetapi usaha belajarnya tidak serius, tidak memiliki kebiasaan belajar yang teratur, mudah bosan ketika melakukan belajar. Kondisi rendahnya motivasi itu membawa akibat pada rendahnya kompetensi yang dikuasai siswa, yang pada gilirannya mengundang munculnya praktik-praktik curang dalam ujian.

Siswa yang mempunyai motivasi berprestasi rendah tidak boleh dibiarkan dan harus mendapatkan perhatian khusus dari seluruh pihak sekolah termasuk guru BK. Apabila dibiarkan akan berpengaruh terhadap kegagalan hasil belajar siswa serta setelah mereka lulus tidak dapat bersaing di dunia kerja dan juga seleksi masuk perguruan tinggi. Penelitian Fatchurrohman (2011) menemukan motivasi berprestasi memiliki pengaruh yang positif dalam menunjang kesiapan belajar peserta didik, dengan demikian motivasi berprestasi akan memberikan dampak positif terhadap kemajuan belajar peserta didik, yang diwujudkan melalui kesungguhsungguhan dalam mempersiapkan kegiatan pembelajaran, selain itu juga motivasi mempunyai kaitan yang positif dalam menunjang keberhasilan meraih prestasi bagi peserta didik

Layanan bimbingan kelompok merupakan salah satu jenis layanan yang dianggap tepat untuk mengembangkan dan meningkatkan motivasi berprestasi pada siswa. Hal ini disebabkan karena dalam layanan bimbingan kelompok banyak informasi-informasi tentang pendidikan, pekerjaan, pribadi, dan sosial. Hasil penelitian dari Narni (2015) Bahwa motivasi berprestasi siswa dapat ditingkatkan melalui kegiatan layanan bimbingan kelompok. Hal ini ditunjukkan dengan tingkat motivasi berprestasi dari 10 siswa yang menjadi anggota kelompok setelah pelaksanaan layanan bimbingan kelompok teknik modeling semuanya masuk kategori tinggi dengan rata-rata $86(90 \%)$.

Pemberian bimbingan kelompok yang bertujuan untuk meningkatkan motivasi berprestasi peserta didik, akan berhasil dan lebih menarik untuk diikuti oleh peserta jika dilakukan dengan menggunakan media film daripada hanya dengan diskusi kelompok yang mengakibatkan siswa cenderung pasif dan tidak ada interaksi. Menurut Sardiman (2011: 68) media film mempunyai beberapa keunggulan yaitu film dapat merangsang atau memotivasi kegiatan anak-anak, film bisa mengatasi keterbatasan daya indera kita (penglihatan), dan film dapat memikat perhatian anak, Film sangat bagus untuk menerangkan suatu proses.

Menurut Susanto (2012) Penggunaan media film dalam proses bimbingan kelompok yang dilakukan dapat meningkatkan kemampuan kreativitas siswa. Untuk pengembangan kreativitas sebaiknya menggunakan media sebagai alat bantu, baik media manual dan sederhana atau multimedia untuk memperoleh hasil yang diinginkan.

Beberapa penelitian tersebut menjelaskan bahwa layanan bimbingan kelompok efektif membantu berbagai permasalahan siswa. Bimbingan kelompok dengan menggunakan media film diharapkan memberikan inovasi baru dan dapat mengatasi kelemahan pada pelaksanaan bimbingan kelompok yang pernah dilakukan yaitu pasifnya anggota kelompok dalam berdiskusi. Dengan menggunakan media film diharapkan dapat merangsang anggota kelompok untuk bisa aktif terlibat dalam kegiatan kelompok dan diharapkan mampu menciptakan dinamika kelompok yang lebih baik lagi. Hal ini lah yang menjadu landasan bagi peneliti melakukan layanan bimbingan kelompok dengan media film untuk meningkatkan motivasi berprestasi siswa

\section{METODE PENELITIAN}

Penelitian ini menggunakan one group pretest-pos design yaitu terdiri satu kelompok yang mempunyai motivasi berprestasi rendah kemudian diberikan treatmen berupa layanan bimbingan kelompok dengan media film. Pelaksaan layanan bimbingan kelompok dengan media film peneliti melibatkan 10 siswa kelas VII dan VIII yang mempunyai motivasi 
berprestasi rendah. Sedangkan 2 orang guru BK di MTs Negeri 2 Pekalongan yang berlatar belakang pendidikan S1 Bimbingan dan Konseling serta 1 orang guru bidang studi sekaligus sebagai walikelas membantu penliti memberikan informasi tentang kondisi motivasi berprestasi siswa MTs Negeri 2 Pekalongan sebelum diberikan treatment.

Teknik pengumpulan data yang digunakan dalam penelitian ini adalah menggunakan skala motivasi berprestasi yang terdiri dari 45 item. Berdasarkan uji validitas dan reliabilitas butir item tersebut dapat diketahui skala motivasi berprestasi siswa dari jumlah 50 item, yang valid 45 item, yang tidak valid ada 5 . Hasil perhitungan uji reliabilitas skala psikologis motivasi berprestasi terhadap siswa sejumlah $\mathrm{N}=40$ siswa, dengan rumus Alpha diperoleh hasil nilai $\mathrm{r}_{11}$ adalah 0,92. Hasil tersebut setelah dikonsultasikan dengan $r$ tabel, dengan $\mathrm{N}=40$ adalah 0,316 dengan taraf signifikansi sebesar 5\%. (tabel $r$ dirujuk dari Sugiyono, 2012: 140). Hal ini mengandung arti bahwa instrumen tersebut memiliki indeks yang tinggi. Sehingga instrumen bersifat handal atau reliable sebagai alat pengumpulan data.

\section{HASIL DAN PEMBAHASAN}

Berdasarkan hasil penelitian awal terhadap 70 siswa menunjukkan bahwa secara global motivasi berprestasi siswa MTs Negeri 2 Pekalongan mencapai 56,4\% pada kategori sedang. Gambaran ini memberikan penjelasan bahwa sebanyak 49 siswa kelas VII dan VIII mempunyai motivasi berprestasi sedang. Tingkat motivasi berprestasi siswa pada kategeri sedang masih perlu ditingkatkan lagi untuk dapat mencapai minimal kategori baik. Tingkat motivasi berprestasi siswa pada kategori sedang apabila dibiarkan maka ditakutkan akan mempengaruhi motivasi siswa dalam menghadapi persaingan untuk mendapatkan pekerjaan dan memasuki perguruan tinggi setelah lulus sekolah.

Terjadi peningkatan motivasi berprestasi siswa antara pre-test dan post-test yaitu dari prosentase $56,7 \%$ menjadi $79,9 \%$ atau meningkat sebesar $23,2 \%$ dan meningkat dari kategori cukup baik menjadi baik. Hal ini disebabkan siswa diberi perlakuan melalui layanan bimbingan kelompok dengan dengan media film yang mengandung pesan moral motivasi berprestasi. Siswa seperti mendapat sebuah inspirasi, stimulus dan semangat baru untuk menjadi seorang yang berprestasi.

Uji keefektifan model bimbingan kelompok dengan media film untuk meningkatkan motivasi berprestasi siswa dianalisa dengan uji statistik non parametrik berupa uji Wilcoxon Match Pairs Test, dimana pertimbangannya adalah apabila digunakan untuk menguji signifikansi hipotesis komparatif dua sampel yang berkorelasi, bila datanya berbentuk ordinal (berjenjang), dan jumlah sampelnya kurang dari 30 responden (Sugiyono, 2012: 44).

Berdasarkan hasil analisis menggunakan uji Wilcoxon diperoleh nilai Asymp. Sig. (2tailed) $=0.005<\alpha=0.05$, maka tolak Ho. Artinya bimbingan kelompok dengan media film dapat meningkatkan motivasi berprestasi siswa. Hal ini sejalan dengan hasil empiris pada tabel Descriptive Statistics dimana terjadi peningkatan skor minimum, maksimum, dan rataan dari pre test ke post tes. Selain itu bila dicermati pada tabel Ranks baris Negative Ranks $=0$, artinya tidak ada ranks yang negatif, dalam hal ini tidak ada skor hasil post test yang lebih kecil daripada skor hasil pre test (Post < Pre), Positive Ranks= 10, artinya semua ranks bertanda positif, dalam hal ini semua skor hasil post test lebih tinggi dibandingkan hasil pre test (Post > Pre).

Tabel 1. Uji data Penelitian

\begin{tabular}{cccccc}
\hline \multicolumn{2}{c}{ Rata-rata } & $\mathrm{Z}$ & Sig & $\begin{array}{c}\text { positive } \\
\text { Ranks }\end{array}$ & Kriteria \\
\hline Pretest & Post test & Z & & & $\begin{array}{c}\text { Terdapat } \\
\text { perbedaan }\end{array}$ \\
\hline
\end{tabular}

Motivasi berprestasi sangat penting dalam kehidupan seseorang karena dengan motivasi berprestasi membuat siswa terus berusaha mencapai prestasi dan hasil belajar yang lebih baik lagi sehingga bisa meraih kesuksesan. Penelitian Fatchurrohman (2011) menemukan motivasi 
berprestasi memiliki pengaruh yang positif dalam menunjang kesiapan belajar peserta didik, dengan demikian motivasi berprestasi akan memberikan dampak positif terhadap kemajuan belajar peserta didik, yang diwujudkan melalui kesungguh-sungguhan dalam mempersiapkan kegiatan pembelajaran, selain itu juga motivasi mempunyai kaitan yang positif dalam menunjang keberhasilan dalam meraih prestasi bagi peserta didik.

Motivasi berprestasi menjadi hal yang sangat untuk terus ditingkatkan dengan tujuan meraih prestasi yang lebih baik. Rendahnya motivasi berprestasi apabila dibiarkan dan tidak segera mendapatkan treatment akan menyebabkan kurangnya semangat untuk belajar, kurangnya keinginan untuk meraih prestasi, kurangnya semangat untuk bersaing. Menurut Toni, Lasmawan \& Arnyana (2013) bahwa Siswa yang mempunyai motivasi berprestasi tinggi cendrung ingin sukses dalam belajarnya. Keberhasilan seseorang dalam mencapai hasil yang terbaik dalam hidupnya pada dasarnya tidak terlepas dengan motivasi belajar, dan harapan suksesnya, serta menghindari kegagalan.Data yang diperoleh peneliti dengan menggunakan skala motivasi berprestasi di MTs Negeri 2 Pekalongan Kabupaten Pekalongan menunjukkan bahwa masih banyak siswa yang mempunyai tingkat motivasi berprestasi rendah hingga sedang. Hasil data tersbut menunjukkan bahwa motivasi berprestasi siswa MTs Negeri 2 Pekalongan perlu ditingkatkan.

Layanan bimbingan kelompok mempunyai peran yang penting dalam membantu meningkatkan motivasi berprestasi. Hasil penelitian dari Narni (2015) Bahwa motivasi berprestasi siswa dapat ditingkatkan melalui kegiatan layanan bimbingan kelompok. Hal ini ditunjukkan tingkat motivasi berprestasi dari 10 siswa yang menjadi anggota kelompok setelah pelaksanaan layanan bimbingan kelompok teknik modeling semuanya masuk kategori tinggi.

Penggunaan media film dalam pelaksanaan bimbingan kelompok selain dapat memberikan alternatif baru juga dapat membantu menyelesaikan masalah serta mempermudah dalam menyampaikan informasi. Hal ini karena menurut Sardiman (2011 : 68) media film mempunyai beberapa keunggulan yaitu film dapat merangsang atau memotivasi kegiatan anakanak, film bisa mengatasi keterbatasan daya indera kita (penglihatan), dan film dapat memikat perhatian anak, Film sangat bagus untuk menerangkan suatu proses. Gerakan-gerakan lambat dan pengulangan-pengulangan akan memperjelas uraian dan ilustrasi, dan film merupakan suatu denominator belajar yang umum, baik anak yang cerdas maupun yang lamban akan memperoleh sesuatu dari film yang sama. Ketrampilan membaca atau penguasaan bahasa yang kurang bisa diatasi menggunakan film.

Pemberian bimbingan kelompok yang bertujuan untuk meningkatkan motivasi berprestasi peserta didik, akan berhasil dan lebih menarik untuk diikuti oleh peserta jika dilakukan dengan menggunakan media film daripada hanya dengan diskusi kelompok yang mengakibatkan siswa cenderung pasif dan tidak ada interaksi. Menurut Susanto (2012) Penggunaan media film dalam proses bimbingan kelompok yang dilakukan dapat meningkatkan kemampuan kreativitas siswa. Untuk pengembangan kreativitas sebaiknya menggunakan media sebagai alat bantu, baik media manual dan sederhana atau multimedia untuk memperoleh hasil yang diinginkan.

Tujuan layanan bimbingan kelompok dengan media film adalah untuk meningkatkan sikap tanggung jawab, berani mengambil resiko, inovatif dan kreatif, serta bekerja keras melalui film dalam kelompok, dimana siswa dapat mencerminkan motivasi berprestasi. Dapat memahami sudut pandang orang lain antar sesama anggota kelompok, tidak berorientasi pada diri sendiri, tetapi pada kepentingan orang lain yang berhubungan dengan motivasi berprestasi.

Siswa melalui diskusi kelompok dalam layanan bimbingan kelompok dengan media film akhirnya secara bertahap terbantu dalam memecahkan berbagai permasalahan yang berhubungan dengan motivasi berprestasi. Selanjutnya siswa memiliki pandangan-pandangan baru, sikap siswa berubah ke arah yang lebih baik dalam motivasi berprestasinya. Dengan adanya layanan bimbingan kelompok dengan media film, siswa berpikiran positif untuk membantu orang lain.

Bimbingan kelompok dengan media film yang diimplementasikan pada siswa MTs 
Negeri 2 PekalonganPekalongan menunjukkan efektivitas dalam meningkatkan motivasi berprestasi siswa. Tingkat motivasi berprestasi siswa sebelum mengikuti bimbingan kelompok dengan media film adalah $56,7 \%$ dan setelah mengikuti bimbingan kelompok dengan media $79,9 \%$, terjadi kenaikan sebesar $23,2 \%$. Peningkatan tersebut terjadi pada semua dimensi motivasi berprestasi.

\section{KESIMPULAN}

Penelitian ini dilakukan untuk meningkatkan motivasi berprestasi siswa kelas VII dan VIII MTs Negeri 2 Pekalongan Kabupaten Pekalongan melalui layanan bimbingan kelompok dengan media film. Hasil penelitan ini menujukkan bahwa layanan konsultasi dengan media film dapat meningkatkan motivasi berprestasi siswa secara signifikan. Hal ini didasarkan pada perolehan nilai pre test dan post test pada skala motivasi berprestasi siswa setelah diberikan bantuan (treatment) oleh peneliti melalui layanan bimbingan kelompok dengan media film.

Guru BK/Konselor sekolah hendaknya menerapkan layanan bimbingan kelompok dengan media film, karena model ini setelah diujicobakan terbukti efektif untuk meningkatkan motivasi berprestasi siswa. Selanjutnya guru BK/Konselor sekolah diharapkan untuk terus mengembangkan kompetensi yang dimilikinya khususnya dalam memberikan layanan bimbingan kelompok dengan media film.

\section{DAFTAR PUSTAKA}

Fatchurrohman.(2011).Pengaruh Motivasi Berprestasi Terhadap Kesiapan Belajar, Pelaksanaan Prakerin dan Pencapaian Kompetensi Mata Pelajaran Produktif Teknik Kendaraan Ringan Kelas XI. ISSN 1415-565 X. No.2

Narni.2015. Upaya Meningkatkan Motivasi Berprestasi Melalui Layanan Bimbingan Kelompok Dengan Teknik Modelling. Jurnal Penelitian TindakanBimbingan dan

Sardiman A. M. (2012). Interaksi dan Motivasi Belajar Mengajar. Jakarta. Raja Grafindo Persada.

Sugiyanto.(2009).Kontribusi Motivasi Berprestasi Terhadap Prestasi Akademik Siswa Kelas XI SMAN 10 Semarang.Paradigma No.8 Th.IV

Sugiyono. (2008). Metode Penelitian Kuantitatif Kualitatif dan R\&D. Bandung. Alfabeta.

Susanto, Eko.2012. Penggunaan Media Film Dalam Proses Bimbingan Kelompok Untuk Mengembangkan Kreativitas. Jurnal Guidena. Vol 2. No.1, 13-27

Taiyeb, Bahri \& Razak. 2012. Analisis Motivasi Berprestasi Siswa SMAN 8 Makassar Dalam Belajar Biologi. Jurnal Bionature. Volume 13, Nomor 2, hlm.77-82

Toni, Lasmawan \& Arnyana. (2013). Determinasi Konsep Diri, Motivasi Berprestasi Dan Disiplin Belajar Terhadap Hasil Belajar IPA SD Se-Kecamatan Buleleng. e-Journal Program Pascasarjana Universitas Pendidikan Ganesha Program Studi Pendidikan Dasar.Volume 3 